\title{
Program pendampingan latihan fisik dalam upaya peningkatan kesehatan mahasiswa Fakultas Kedokteran Universitas Sriwijaya pada masa adaptasi kebiasaan baru
}

\author{
Eka Febri Zulissetiana $^{1 *}$, Arwan Bin Laeto ${ }^{1}$, Budi Santoso ${ }^{1}$, Syifa Alkaf ${ }^{1}$, Nyimas Fatimah ${ }^{2}$ \\ ${ }^{1}$ Bagian Fisiologi dan Fisika Medik, Fakultas Kedokteran, Universitas Sriwijaya \\ ${ }^{2}$ Bagian Ilmu Kedokteran Fisik dan Rehabilitasi , Fakultas Kedokteran, Universitas Sriwijaya \\ E-mail: dr.eka_1902@yahoo.com
}

\begin{abstract}
Abstrak
Gaya hidup menetap merupakan gaya hidup yang ditandai dengan rendahnya aktivitas fisik yang dapat menyebabkan peningkatan risiko terjadinya berbagai gangguan atau penyakit. Makin meluasnya pandemi Covid-19 saat ini menyebabkan adanya pembatasan sosial sehingga secara signifikan mengubah pola aktivitas fisik. Pemberian edukasi dan pendampingan serta pemberdayaan mahasiswa untuk melakukan latihan fisik secara rutin merupakan strategi yang tepat untuk merubah pola aktivitas fisik dalam rangka meningkatkan derajat kesehatan di masa adaptasi kebiasaan baru. Kegiatan pengabdian masyarakat ini dilakukan kepada 36 orang mahasiswa Fakultas Kedokteran Universitas Sriwijaya berupa pemberian penyuluhan dan edukasi rutin. Kegiatan juga disertai upaya pendampingan serta pemberdayaan mahasiswa untuk melakukan latihan fisik secara rutin selama 1 bulan. Penilaian keberhasilan pengabdian masyarakat ini dilakukan dengan menilai peningkatan pengetahuan peserta sebelum dan sesudah kegiatan, tercapainya target langkah kaki untuk semua peserta selama sesi latihan dan juga kuisioner manfaat latihan fisik secara rutin. Hasil penilaian pengetahuan didapatkan rerata nilai hasil posttest peserta $(4,86)$ yang meningkat dibandingkan dengan saat pretest $(3,7)$. Selama kegiatan, seluruh peserta $(100 \%)$ melaksanakan latihan fisik secara teratur dengan frekuensi 3 kali seminggu dan setelah 1 bulan seluruh peserta merasakan manfaat diantaranya badan terasa segar $(100 \%)$, lebih termotivasi untuk berolahraga $(83,3 \%)$, lebih bugar $(69,4 \%)$, konsentrasi meningkat $(66,7 \%)$, penurunan berat badan $(41,6 \%)$, lebih bersemangat $(8,3 \%)$ dan tidur lebih nyenyak $(2,7 \%)$. Kegiatan penyuluhan dan pendampingan dapat dilakukan untuk meningkatkan pengetahuan dan pembiasaan masyarakat dalam melakukan latihan fisik terutama di masa pandemi covid 19 ini.
\end{abstract}

Kata kunci: Latihan Fisik, Gaya Hidup Menetap, Covid-19

\begin{abstract}
Physical exercise assistance program to improve the health of students of the Faculty of Medicine, Sriwijaya University in the new normal era. Sedentary lifestyle is a lifestyle characterized by low physical activity that can lead to an increased risk of various disorders or diseases. The widespread Covid-19 pandemic is currently causing social restrictions that significantly change the pattern of physical activity. Providing education and mentoring and empowering students to do physical exercise regularly is the right strategy to change the pattern of physical activity to improve the degree of health in the adaptation of new habits. This community service activity was carried out to 36 students of the Faculty of Medicine, Sriwijaya University in the form of providing regular counseling and education. The activity was also accompanied by mentoring efforts and empowering students to do physical exercise regularly for 1
\end{abstract}


month. The assessment of the success of community service was carried out by assessing the increase in participants knowledge before and after the activity, achieving the footing target for all participants during the training session and also questionnaires on the benefits of regular physical exercise. Knowledge assessment results obtained the average value of posttest results of participants (4.86) which increased compared to the pretest (3.7). During the activity, all participants $(100 \%)$ carry out regular physical exercise with a frequency of 3 times a week and after 1 month all participants felt the benefits including a fresh body feeling (100\%), more motivated to exercise (83.3\%), fitter (69.4\%), increased concentration $(66.7 \%)$, weight loss $(41.6 \%)$, more vigorous $(8.3 \%)$ and sleep better $(2.7 \%)$ From this community service activity, it can be concluded that counseling and mentoring activities can be done to increase knowledge and habituation of the community in conducting physical exercises, especially during the Covid-19 pandemic.

Keywords: Exercise, Sedentary Lifestyle, Covid-19

\section{PENDAHULUAN}

Perkembangan dan kemajuan di bidang teknologi memberikan perubahan signifikan pada gaya hidup masyarakat modern terutama dalam hal minimnya aktivitas fisik. ${ }^{1}$ Data Riset Kesehatan Dasar tahun 2018 menunjukkan proporsi aktivitas fisik penduduk umur >10 tahun di Provinsi Sumatera Selatan sebanyak 36\% masih beraktivitas kurang dan jumlah ini mengalami peningkatan dari tahun 2013 dan lebih tinggi dari rerata secara nasional $(33,5 \%)^{2}$

Ditambah lagi, pada Maret 2020, penyakit pernafasan yang disebabkan oleh virus SARS-COV-2, Covid-19 telah diumumkan sebagai suatu pandemi oleh WHO dan suatu kedaruratan kesehatan nasional di Indonesia. Seiring dengan terus meningkatnya kasus di hampir seluruh wilayah di dunia membuat pihak yang berwenang mengatur berbagai restriksi seperti anjuran untuk tetap tinggal di rumah, penutupan sekolah dan universitas, larangan perjalanan, acara budaya dan olahraga serta berbagai pertemuan sosial sebagai strategi untuk mencegah penyebaran Covid-19 ini. Berbagai kebijakan ini menimbulkan dampak negatif berupa menurunnya aktivitas fisik dan lebih banyak waktu yang dihabiskan dengan duduk di depan layar sehingga pola aktivitas fisik berubah menjadi pola aktivitas fisik yang bersifat sedentary life. . $^{3,4}$

Sedentary lifestyle merupakan gaya hidup menetap, tak berpindah, yang waktunya banyak dihabiskan hanya untuk duduk dan dilakukan secara terus menerus. Gaya hidup 
seperti ini akan menyebabkan aktivitas fisik menjadi rendah yang kemudian dapat menyebabkan peningkatan risiko terjadinya berbagai gangguan atau penyakit, seperti overweight, obesitas, diabetes mellitus, hipertensi dan penyakit kardiovaskular. ${ }^{5}$ Oleh karena itu, dalam menjalani kehidupan adaptasi kebiasaan baru, mahasiswa harus tetap konsisten melakukan aktivitas fisik. Aktivitas fisik yang dilakukan secara terencana dan terprogram dalam bentuk latihan akan memberikan bentuk adaptasi yang akan mengoptimalkan kapasitas dan efisiensi tubuh. ${ }^{6}$

Upaya pemberian pendidikan kesehatan melalui edukasi dan penyuluhan diharapkan dapat merubah perilaku individu dan kelompok mahasiswa. Ditambah lagi, upaya pendampingan dan pemberdayaan mahasiswa untuk melakukan latihan fisik secara rutin merupakan strategi tambahan yang diharapkan akan memperkuat proses perubahan perilaku kesehatan terkait peranan latihan fisik dalam meningkatkan derajat kesehatan mahasiswa di masa adaptasi kebiasaan baru ini.

\section{TINJAUAN PUSTAKA}

Latihan fisik adalah suatu bentuk aktivitas fisik yang melibatkan setiap gerakan tubuh yang mengeluarkan energi dan bersifat terencana, terstruktur, berulang dan bertujuan untuk meningkatkan dan mempertahankan kebugaran fisik. ${ }^{7}$ Latihan fisik dapat mempengaruhi hampir semua sistem yang ada di tubuh seperti sistem kardiovaskular, sistem imunitas, metabolisme, respirasi, fungsi endokrin dan sistem saraf pusat. Manfaat latihan fisik pada sistem kardiovaskular meliputi: penyediaan oksigen dan nutrisi, mengeliminasi karbon dioksida dan hasil akhir metabolisme, menjaga suhu tubuh dan keseimbangan asam basa serta transport hormone. Secara umum latihan fisik akan meningkatkan detak jantung serta meningkatkan stroke volume sehingga terjadi peningkatan cardiac output. ${ }^{8,9}$ Dengan latihan fisik yang teratur terjadi penurunan kebutuhan oksigen, meningkatkan suhu tubuh serta meningkatkan ventilasi pulmonal. ${ }^{8}$ Manfaat latihan fisik terhadap sistem endokrin berupa peningkatan kortisol sehingga menjaga kadar gula darah tetap stabil, meningkatkan 
growth hormone sehingga memobilisasi asam lemak bebas dan menjaga gula darah, serta meningkatkan hormon tiroid yang meningkatkan kecepatan metabolism. ${ }^{8}$ Latihan fisik juga memiliki manfaat dalam pengembangan kognitif. Latihan fisik dapat meningkatkan perhatian, pengolahan informasi, dan memori. Latihan fisik dapat meningkatkan ekspresi gen dan faktor yang mempengaruhi neuroplastisitas dan plastisitas sinaps seperti brainderived neurotrophic factor (BDNF), insulin-like growth factor 1 (IGF-1) dan postsynaptic density protein 95 (PSD95). ${ }^{10,11}$ Olahraga akan merangsang proliferasi populasi progenitor neuron, meningkatkan jumlah neuron baru, dan membantu kelangsungan hidup neuron sehingga meningkatkan kemampuan mengingat jangka pendek dan jangka panjang. ${ }^{8}$

Latihan fisik setidaknya harus menerapkan 4 prinsip dasar yaitu frequency, intensity, time dan type (FITT). Frekuensi didefinisikan sebagai jumlah hari per minggu yang didedikasikan oleh seseorang untuk melakukan latihan fisik. Intensitas menunjukkan seberapa sulit aktivitas tersebut berdasarkan tingkat pengeluaran energi. Durasi menunjukkan seberapa lama latihan fisik dilakukan sedangkan tipe menunjukkan jenis latihan fisik yang dilaksanakan. ${ }^{12,13}$

Pada akhir tahun 2019, muncul suatu virus baru (SARS-CoV-2) (COVID-19), penyebab sindrom pernapasan akut yang meluas secara global dan secara signifikan mengubah pola aktivitas fisik populasi. Dengan adanya rekomendasi isolasi sosial dan pembatasan perilaku sehari-hari, mengubah pola aktivitas fisik menjadi sedentary lifestyle. ${ }^{4,14}$ Oleh karena itu, WHO menerbitkan rekomendasi agar masyarakat dapat melakukan latihan fisik setidaknya 150 menit per minggu. Rekomendasi ini dapat dilakukan di rumah, tanpa peralatan khusus dan dengan ruang terbatas. ${ }^{15}$ Sebagai tambahan, beberapa rekomendasi yang juga diperlukan untuk memastikan penurunan risiko infeksi pada saat melakukan latihan fisik terutama jika dilakukan di fasilitas publik termasuk menjaga jarak sosial setidaknya 2 meter, desinfeksi rutin peralatan, mencegah orang sakit mengunjungi fasilitas olahraga, dan tetap menggunakan masker wajah. ${ }^{15,16}$ 


\section{METODE}

Pelaksanaan kegiatan pengabdian masyarakat ini dilakukan secara daring dengan sasaran mahasiswa Program Studi Pendidikan Dokter Fakultas Kedokteran Universitas Sriwijaya dengan rincian rentang usia 18-22 tahun. Pelaksanaan kegiatan terdiri dari 3 kegiatan sebagai berikut:

1. Penyuluhan, dilakukan dengan ceramah dengan alat bantu berupa power point dan poster yang akan diberikan secara daring melalui media zoom. Selain itu dilakukan diskusi dengan peserta tentang bagaimana selama ini paradigma mengenai latihan fisik, pola aktivitas fisik di rumah maupun di kampus selama ini dan perubahan aktivitas di masa pandemi, gaya hidup sedentary, bahayanya sehingga dapat diatasi melalui perubahan pola hidup. Penyuluhan juga akan memberikan edukasi mengenai definisi, intensitas, contoh latihan fisik, manfaat latihan fisik untuk kesehatan serta persiapan yang harus dilakukan sebelum memulai latihan fisik.

2. Pendampingan, dilakukan selama 1 bulan dengan memberikan program latihan fisik aerobik intensitas ringan-sedang tiap 3 kali seminggu selama 50-60 menit. Untuk memudahkan pendampingan, Peserta bergabung dalam 1 kelompok dengan semua anggota tim melalui grup Line®. Setiap 3 kali seminggu, tim memberikan motivasi dan edukasi dalam bentuk e-leaflet berisi berbagai informasi dan ajakan secara berkala.

Latihan fisik aerobik intensitas ringan-sedang diukur dengan menggunakan target frekuensi nadi 50-75 \% dari frekuensi nadi maksimal. Dari hasil target frekuensi nadi ini kemudian dikonversikan ke langkah kaki sehingga lebih mempermudah dalam menghitung target masing-masing. Dengan memperhatikan kebugaran dan kebiasaan masing-masing peserta tidak sama, maka intensitas latihan fisik juga dinaikkan secara bertahap setiap minggunya mulai dari 3500-4500 langkah.

3. Pemantauan, dilakukan untuk mengetahui keberhasilan dari pendampingan latihan fisik dengan cara memantau aktivitas (langkah kaki) peserta via aplikasi Pacer®. 
Pemantauan rutin secara berkala juga dilakukan melalui grup Line ${ }^{\circledR}$ untuk melihat kemungkinan cedera dan keluhan lain selama melakukan latihan fisik

\section{HASIL DAN PEMBAHASAN}

Kegiatan ini dilaksanakan pada tanggal 1-30 November 2020 dan diikuti oleh 36 orang peserta. Sebelum dilakukan program ini, para peserta diminta mengisi kuisioner melalui google form untuk menilai rutinitas dan frekuensi latihan fisik sebelum dilakukan pendampingan ini.

Tabel 1. Distribusi Frekuensi Latihan Fisik sebelum dan selama pendampingan $(\mathrm{n}=36)$

\begin{tabular}{lcc}
\hline Latihan Fisik & Sebelum pendampingan & Selama pendampingan \\
\hline $\begin{array}{c}\text { Rutinitas Latihan Fisik } \\
\text { Ya }\end{array}$ & $9(25 \%)$ & $36(100 \%$ \\
Tidak & $27(75 \%)$ & $0(0 \%)$ \\
\hline Frekuensi Latihan Fisik & & \\
$<3$ kali seminggu & $15(41,67 \%)$ & $0(0 \%)$ \\
$\geq 3$ kali seminggu & $9(25 \%)$ & $36(100 \%)$ \\
1 kali/bulan & $12(33,3 \%)$ & $0(0 \%)$ \\
\hline
\end{tabular}

Tabel di atas menunjukkan sebelum mengikuti kegiatan pengabdian ini, sebagian besar peserta tidak rutin melakukan latihan fisik dan sebagian besar melakukan latihan fisik kurang dari 3 kali seminggu. Sehingga program pendampingan ini diharapkan dapat mendorong peserta agar meningkatkan frekuensi latihan fisik secara rutin.

Kegiatan kemudian dilanjutkan dengan penyampaian materi oleh 2 orang narasumber yaitu dr. Eka Febri Zulissetiana, M. Bmd dan dr. Budi Santoso, M. Kes dengan menggunakan bantuan media power point mengenai kebugaran fisik dan olahraga yang dianjurkan pada saat pandemi Covid-19. Materi yang disampaikan berisi penjelasan mengenai manfaat latihan fisik di semua sistem tubuh, prinsip FITT pada latihan fisik, jenisjenis latihan fisik serta manfaat dan contohnya (aerobik, penguatan, peregangan, keseimbangan, relaksasi dan pernafasan), persiapan sebelum memulai latihan fisik, dan 
hal-hal yang harus diperhatikan pada saat latihan fisik terutama pada saat pandemi Covid19 ini. Selama proses dan setelah sesi penyuluhan terlihat antusiasme dari para mahasiswa dari yang terlihat dari feedback dan pertanyaan serta diskusi yang diajukan di akhir sesi.

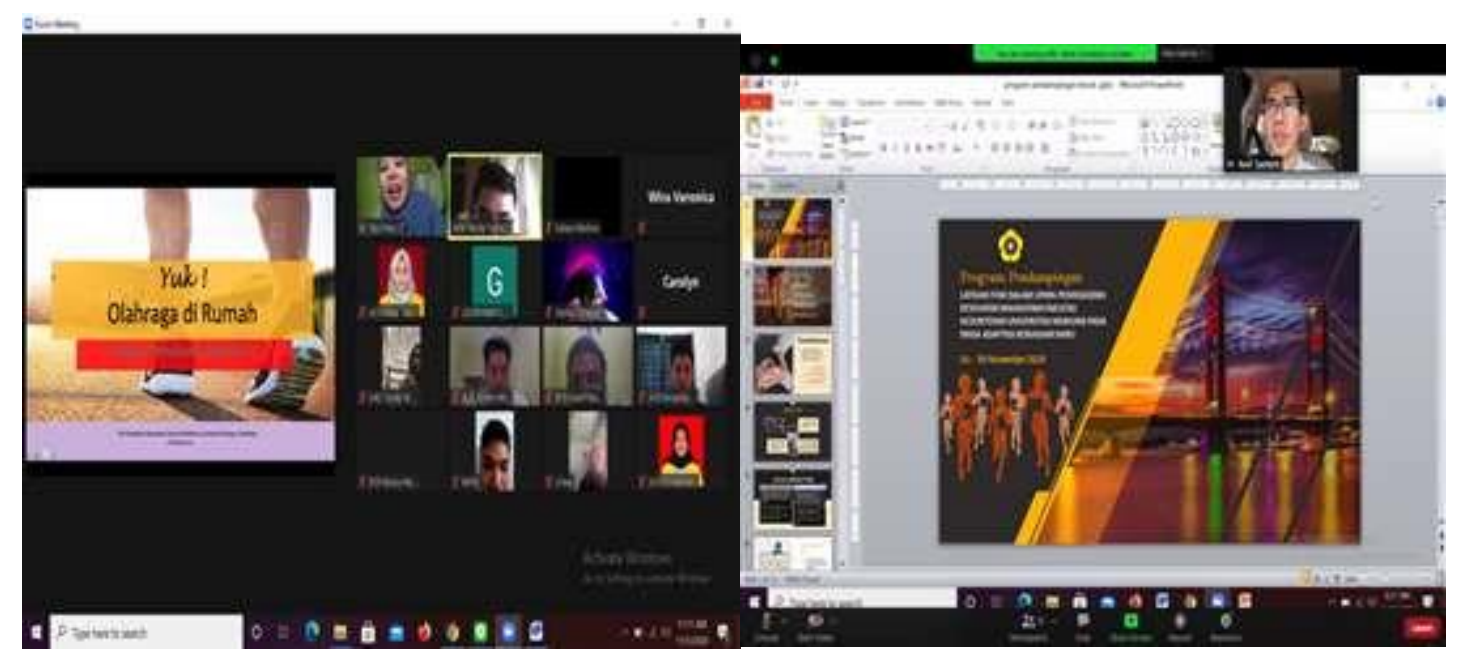

Gambar 1. Suasana Pemberian Penyuluhan

(a) Penyuluhan ke 1 (b) Penyuluhan ke 2

Selain itu, untuk menilai secara objektif apakah pengetahuan tentang materi yang disampaikan diterima dengan baik, mahasiswa juga diberikan pretest dan posttest terkait materi yang telah disampaikan oleh narasumber. Jumlah soal yang diberikan berjumlah 5 pertanyaan tertutup berisi pengetahuan mahasiswa mengenai manfaat, jenis dan prinsip olahraga di masa pandemi ini. Hasil pretest dan posttest dapat dilihat dari tabel di bawah ini.

Tabel. 2 Hasil pretest dan posttest penyuluhan (Rentang nilai 0-5)

\begin{tabular}{lccccc}
\hline & Mean & Median & Nilai Max & Nilai Min & Standar Deviasi \\
\hline Hasil Pretest & 3,7 & 3 & 5 & 1 & 2,12 \\
Hasil Posttest & 4,86 & 5 & 5 & 4 & 0,707 \\
\hline
\end{tabular}


Dari tabel di atas dapat dilihat bahwa rerata pengetahuan peserta sebelum dan sesudah pemberian edukasi meningkat. Semua peserta juga mampu menjawab lebih dari 80 persen pertanyaan yang diberikan.

Setelah diberikan penyuluhan awal seperti yang telah dijelaskan di atas, agar latihan fisik dapat diterapkan dan menjadi kebiasaan pada mahasiswa, maka tim juga melakukan pendampingan melalui media sosial via Whatsapp ${ }^{\circledR}$ dan Pacer Health ${ }^{\circledR}$. Sebelum dimulai program pendampingan, 1 hari sebelumnya, tim akan mengingatkan melalui grup LINE® sehingga peserta dapat mempersiapkan waktu untuk program latihan fisik keesokan harinya. Latihan fisik yang ditawarkan kepada peserta berupa jalan cepat dan senam aerobik secara bergantian. Selama pendampingan, tim pengmas memantau proses latihan fisik untuk melihat apakah target langkah kaki tercapai dan apakah terdapat keluhan selama program latihan tersebut.

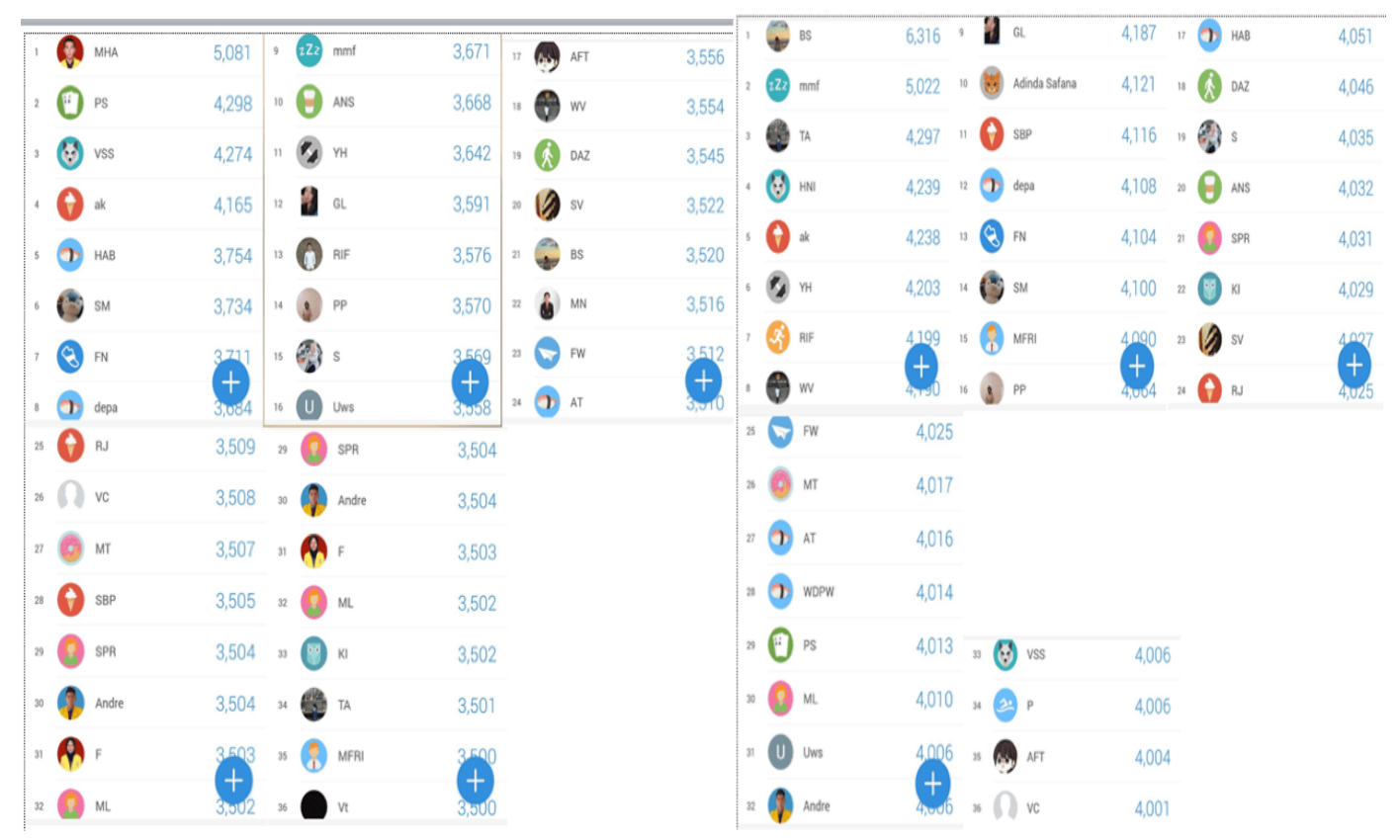

Gambar 2. Pengambilan Langkah kaki menggunakan aplikasi Pacer Health®

(a) Minggu 1 (b) Minggu 2 


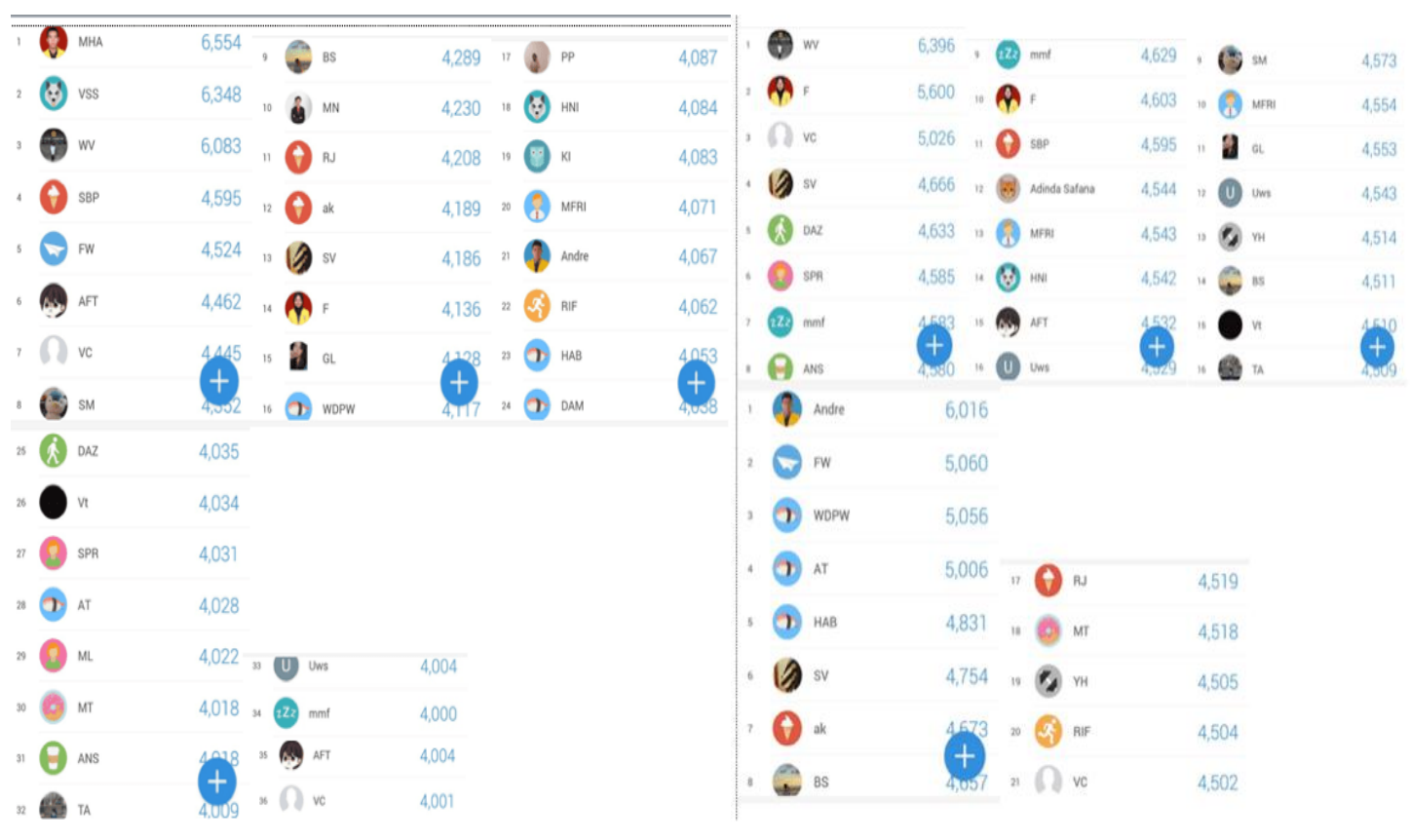

Gambar 3. Pengambilan Langkah kaki menggunakan aplikasi Pacer Health ${ }^{\circledR}$

(a) Minggu 3 (b) Minggu 4

Pada akhir sesi pendampingan ini, dilakukan pertemuan/evaluasi akhir melalui daring. Pada kegiatan ini, dilaporkan hasil pencapaian masing-masing peserta selama 1 bulan dan perwakilan peserta juga memaparkan kesan dan manfaat yang dirasakan selama mengikuti program pendampingan latihan fisik ini. Berbagai manfaat yang dirasakan oleh peserta dapat dilihat dari grafik di bawah ini. 


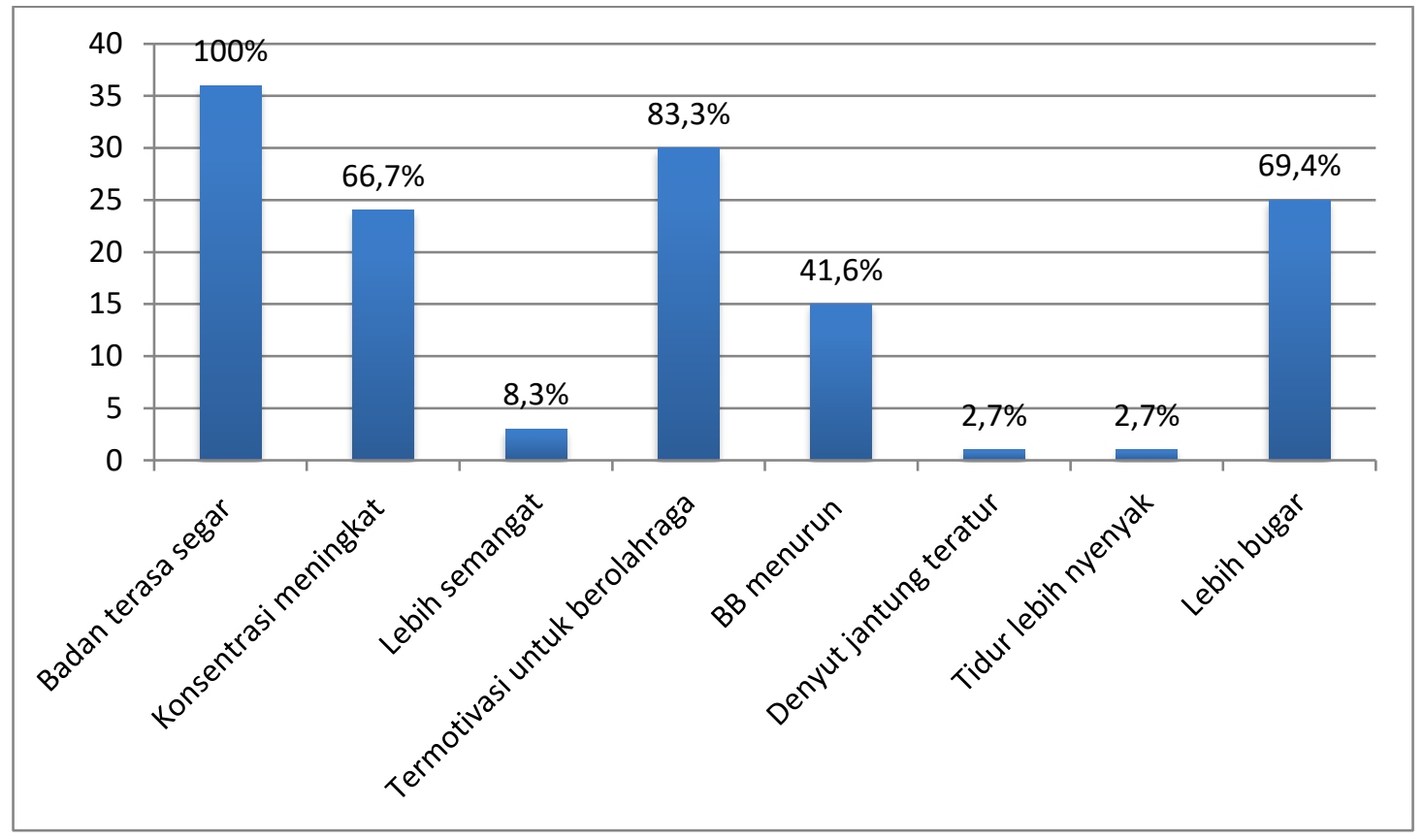

Gambar 4. Manfaat pendampingan latihan fisik yang dirasakan peserta

Dari gambar di atas dapat kita lihat sebagian besar peserta merasakan beberapa manfaat sekaligus. Manfaat terbanyak yang dirasakan oleh peserta adalah badan terasa segar dan bugar serta dengan adanya program pendampingan ini peserta lebih termotivasi untuk berolahraga.

\section{SIMPULAN}

Setelah kegiatan pengabdian masyarakat ini, sebagian besar peserta memiliki pengetahuan tentang bagaimana melakukan latihan fisik selama pandemi Covid-19. Pendampingan yang dilakukan selama pengabdian masyarakat ini juga bermanfaat meningkatkan frekuensi latihan fisik yang dilakukan oleh peserta secara rutin. Peserta juga merasakan berbagai manfaat selama melakukan latihan fisik selama 1 bulan secara rutin. Kegiatan penyuluhan dan pendampingan dapat dilakukan untuk meningkatkan pengetahuan dan pembiasaan masyarakat dalam melakukan latihan fisik terutama di masa pandemi covid 19 ini. 


\section{Ucapan Terima Kasih}

Terima kasih kepada Rektor Universitas Sriwijaya, Dekan Fakultas Kedokteran Universitas

Sriwijaya, dan Kepala Bagian Fisiologi dan Fisika medik yang telah memfasilitasi dan membantu terlaksananya kegiatan pengabdian masyarakat ini.

\section{Referensi}

1. Kurdaningsih S, Sudargo T, Lusmilasari L. Physical activity and sedentary lifestyle towards teenagers' overweight/obesity status. Int J Community Med Public Heal. 2016;3(3):630-635.

2. Ministry of Health Republic of Indonesia. Basic Health Research Report of Indonesia Year 2018 (Laporan Nasional Riskesdas 2018).; 2018.

3. Dunton G, Wang S, Do B, Courtney J. Early Effects of the COVID-19 Pandemic on Physical Activity Locations and Behaviors in Adults Living in the United States. Preventive MedicineReports, 101241.; 2020.

4. Hammami A, Harrabi B, Mohr M, Krustrup P. Physical activity and coronavirus disease 2019 (COVID-19): specific recommendations for home-based physical training. Manag Sport Leis. 2020:1-6.

5. González K, Fuentes J, Márquez J. Physical inactivity, sedentary behavior and chronic diseases. Korean J Fam Med. 2017;38(3):111.

6. Rivera-Brown A, Frontera W. Principles of exercise physiology: responses to acute exercise and long-term adaptations to training. PM R. 2012;4(11):797-804. doi:doi: 10.1016/j.pmrj.2012.10.007

7. Caspersen C, Powell K, Christenson G. Physical activity, exercise, and physical fitness: definitions and distinctions for health-related research. Public Heal rep. 1985;100(2):126131.

8. McMorris T, Davranche K, Jones G, Hall B, Corbett J, Minter C. Acute incremental exercise, performance of a central executive task, and sympathoadrenal system and hypothalamic-pituitary-adrenal axis activity. Int J Psychophysiol. 2009;73(3):334-340.

9. Winter E, Jones A, Davison R, Bromley P, Mercer TH (Eds. . Sport and Exercise Physiology Testing Guidelines: Volume I-Sport Testing: The British Association of Sport and Exercise Sciences Guide. Routledge.; 2006.

10. Irfannuddin I, Zulissetiana E, Suryani P. Effect of Low Intensity Exercise toward Postsynaptic Density 95 Level and Spatial Memory in Male Swiss Webster Mice Induced by Immobilization Stress. J Res Med Dent Sci. 2017;6:438-445.

11. Lee T, Wong M, Lau B, Chia-Di Lee J, Yau S, So K. Aerobic exercise interacts with neurotrophic factors to predict cognitive functioning in adolescents. Psychoneuroendocrinology. 2014;39:214-224.

12. Miles L. Physical activity and health. Nutr Bull. 2007;32(4):314-363.

13. American College of Sports Medicine. ACSM's Guidelines for Exercise Testing and 
Prescription. 10th ed. Philadelphia: Wolters Kluwer; 2008.

14. Chagas E, Biteli P, Candeloro B, Rodrigues M, Rodrigues P. Physical exercise and COVID-19: a summary of the recommendations. AIMS Bioeng. 2020;7(4):236-241.

15. WHO. Coronavirus disease (COVID-19): Staying Active. https://www.who.int/newsroom/q-a-detail/coronavirus-disease-covid-19-staying-active. Published 2020.

16. Epstein D, Korytny A, Isenberg Y, et al. Return to training in the COVID-19 era: The physiological effects of face masks during exercise. Scand J Med Sci Sport. 2020. 